\title{
Spatholobus suberectus Column Extract Inhibits Estrogen Receptor Positive Breast Cancer via Suppressing ER MAPK PI3K/AKT Pathway
}

\author{
Jia-Qi Sun, ${ }^{1}$ Gan-Lin Zhang, ${ }^{1}$ Yi Zhang, ${ }^{1}$ Nan Nan, ${ }^{1}$ Xu Sun, ${ }^{1}$ Ming-Wei Yu, \\ Hong Wang, ${ }^{2}$ Jin-Ping Li, ${ }^{1,3}$ and Xiao-Min Wang ${ }^{1}$ \\ ${ }^{1}$ Department of Oncology, Beijing Hospital of Traditional Chinese Medicine Affiliated to Capital Medical University, Beijing, China \\ ${ }^{2}$ Beijing Institute of Traditional Chinese Medicine, Beijing Hospital of Traditional Chinese Medicine Affiliated to \\ Capital Medical University, Beijing, China \\ ${ }^{3}$ Department of Medical Biochemistry and Microbiology, Uppsala University, 75123 Uppsala, Sweden
}

Correspondence should be addressed to Xiao-Min Wang; wangxiaomin_bhtcm@126.com

Received 1 August 2016; Revised 12 October 2016; Accepted 9 November 2016

Academic Editor: Alaa Amash

Copyright (C) 2016 Jia-Qi Sun et al. This is an open access article distributed under the Creative Commons Attribution License, which permits unrestricted use, distribution, and reproduction in any medium, provided the original work is properly cited.

\begin{abstract}
Although Chinese herbal compounds have long been alternatively applied for cancer treatment in China, their treatment effects have not been sufficiently investigated. The Chinese herb Spatholobus suberectus is commonly prescribed to cancer patients. HPLC analysis has shown that the main components of Spatholobus suberectus are flavonoids that can be classified as phytoestrogens, having a structure similar to estrogen. This study was designed to investigate the effects of Spatholobus suberectus column extract (SSCE) on the estrogen receptor-positive (ER+) breast cancer cell line MCF-7 and its possible molecular mechanism. In our study, MTT assay was performed to evaluate cell viability. The results show that SSCE $(80,160$, and $320 \mu \mathrm{g} / \mathrm{ml})$ significantly decreased the viability of MCF-7 cells. SSCE also triggered apoptosis, arrested the cell cycle at the G0/G1 phase, and inhibited cell migration. A dual-luciferase reporter system showed that SSCE suppressed intranuclear p-ER activity; Western blot analysis confirmed the repressed expression of phosphorylated-ER alpha (p-ER $\alpha$ ), ERK1/2, p-ERK1/2, AKT, p-AKT, p-mTOR, PI3K, and pPI3K, indicating that SSCE suppressed the MAPK PI3K/AKT signaling pathway. Collectively, our results suggest that SSCE causes apoptosis, an arrest in the G0/G1 phase, and a decrease in migration in ER+ MCF-7 cells via hypoactivity of the ER and suppression of the MAPK PI3K/AKT pathway.
\end{abstract}

\section{Introduction}

Breast cancer is the most common malignancy and the leading cause of cancer-related morbidity and mortality among women worldwide [1]. Endocrine therapy represents a major treatment in all settings of the disease for estrogen receptorpositive breast cancers, which account for approximately $70 \%$ of mammary malignancies [2]. In this subgroup of breast cancers, endocrine therapies are effective both in the adjuvant and in the recurrent settings; however, resistance remains a major issue [3].

Spatholobus suberectus Dunn, belonging to the legume family (Fabaceae), is called "chicken blood vines" in China due to its red juice, similar in appearance to blood, that flows out when the vine is injured [4]. It has been used to treat a variety of diseases such as anemia [5], menoxenia, and rheumatism in traditional Chinese medicine $[6,7]$. The Taiwanese National Health Insurance Research Database showed that Spatholobus suberectus is the 8 th most common single herb in adjunctive Chinese herbal medicine therapy for chronic myeloid leukemia patients, and Chinese herbal medicine therapy improves the survival of patients with chronic myeloid leukemia [8]. A few studies have been conducted reporting various types of flavonoids as the principal characteristic components in this herb [9]. Flavonoids are phytoestrogens, which have a similar structure to estrogen and can bind to estrogen receptors. 
TABLE 1: The components of SSCE detected by HPLC.

\begin{tabular}{lcc}
\hline Peak & Components & Ratio in subfraction \\
\hline 1 & Protocatechuic acid & $0.704 \%$ \\
2 & Unknown & $1.183 \%$ \\
3 & p-Hydroxybenzoic acid & $0.486 \%$ \\
4 & Epicatechin & $0.927 \%$ \\
5 & Puerarin & $0.800 \%$ \\
6 & Unknown & $2.836 \%$ \\
7 & Unknown & $1.890 \%$ \\
8 & Daidzein & $9.504 \%$ \\
9 & Glycyrrhizin & $4.369 \%$ \\
10 & Calycosin & $4.555 \%$ \\
11 & Unknown & $5.340 \%$ \\
12 & Genistein & $7.204 \%$ \\
13 & Formononetin & $39.418 \%$ \\
14 & Unknown & $9.221 \%$ \\
15 & Unknown & $8.276 \%$ \\
16 & Prunetin & $3.288 \%$ \\
\hline
\end{tabular}

As an alternative therapy, traditional Chinese herb medicine is becoming accepted by more and more patients for controlling cancer [10], especially in the population who cannot tolerate increasingly intense conventional chemotherapy. Spatholobi Caulis is wildly used by mammary tumor patients in China; however, to date, its treatment effects and potential mechanisms have not been sufficiently investigated. It is of great importance to elucidate the effective mechanisms to support the clinical use of Spatholobi Caulis in ER-positive breast cancer patients. Our present research was designed to examine the effects of the extracts from Spatholobus suberectus (SSCE) on the functions of ER+ MCF-7 cells. The results show that SSCE inhibited cell growth via suppression of the MAPK PI3K/AKT pathway.

\section{Material and Methods}

2.1. Preparation of SSCE. Spatholobus suberectus column extract (SSCE) was prepared by the Beijing Institute of traditional Chinese Medicine. Spatholobus suberectus was obtained from Beijing Xinglin Pharmaceutical Co., Ltd. (place of production: Yunnan, Lot number: 11062601). Spatholobus suberectus $(100 \mathrm{~g})$ was extracted in $80 \%$ ethanol $(500 \mathrm{ml})$ at room temperature over night followed by $2 \mathrm{~h}$ heating-refluxing extraction three times. After cooling down to room temperature, the mixture was filtered through a 180-mesh sieve, and the solvent was removed. The crude extract of Spatholobus suberectus was dissolved in deionized water and centrifuged (3500 $\left.\mathrm{rmin}^{-1}, 20 \mathrm{~min}\right)$. The supernatant was collected and analyzed on a polyamide resin column $(\Phi 1 \mathrm{~cm}$, column height $11 \mathrm{~cm})$. The column was eluted with deionized water and the elute was extracted with three passes of diethyl ether $(10,10$, and $5 \mathrm{ml})$ and pooled. The ether was evaporated and $276 \mathrm{mg}$ of SSCE was obtained. The chemical composition of SSCE was determined by HPLC analysis (Beijing Institute of Traditional Chinese Medicine) as summarized in Table 1.
2.2. Chemicals, Reagents, and Antibodies. Bax and p-ER $\beta$ were purchased from Abcam (Cambridge, MA, USA). Other antibodies were all purchased from Cell Signaling Technology (Danvers, MA, USA). Cell culture medium (DMEM), penicillin-streptomycin, and fetal bovine serum (FBS) were purchased from Gibco (NY, USA). The plasmid was purchased from Promega. The dual-luciferase assay kit was purchased from Vigorous (Beijing, China). All primers were synthesized by Invitrogen $^{\mathrm{TM}}$, Thermo Fisher Scientific.

2.3. Cell Culture. Human ER+ breast cancer cells (MCF-7) were obtained from The Basic Medical Research Institute of Medical Sciences Chinese cell resource center. The cells were cultured in high glucose DMEM medium supplemented with $10 \%$ fetal bovine serum (FBS) and $1 \%$ penicillin-streptomycin and incubated at $37^{\circ} \mathrm{C}$ in a humidified atmosphere with $5 \%$ $\mathrm{CO}_{2}$. The media was changed to DMEM without phenol red (Gibco number 31053-028) and 10\% charcoal-stripped fetal bovine serum (Gibco number 12676-029) with 1\% penicillinstreptomycin $24 \mathrm{~h}$ prior to the experiments.

2.4. Cell Viability Assay. MTT assay was performed to quantify cell viability. MCF-7 cells were seeded into 96-well plates $\left(2 \times 10^{3}\right.$ cells per well) for $24 \mathrm{~h}$ and then exposed to various concentrations of E2 $\left(10^{-4}, 10^{-5}, 10^{-6}, 10^{-7}, 10^{-8}, 10^{-9}, 10^{-10}\right.$, $10^{-11}$, and $\left.10^{-12} \mathrm{M}\right), \operatorname{SSCE}(0,40,80,160$, and $320 \mu \mathrm{g} / \mathrm{ml})$, and $\mathrm{E} 2$ at $10^{-8} \mathrm{M}$ coincubated with $\operatorname{SSCE}(0,40,80,160$, and $320 \mu \mathrm{g} / \mathrm{ml})$. After 24,48 , and $72 \mathrm{~h}$, the cells were incubated with 3-[4,5-dimethylthiazol-2-yl]-2,5-diphenyl tetrazolium bromide (MTT) at $5 \mathrm{mg} / \mathrm{ml}$ and $10 \mu \mathrm{l} /$ well for $4 \mathrm{~h}$. The culture medium was then discarded, and cells were lysed in DMSO with gentle shaking for $15 \mathrm{sec}$. The optical density (OD) values were measured at $570 \mathrm{~nm}$ using a Multiskan Spectrum (Thermo Scientific, USA). Experiments were performed in triplicate.

2.5. Flow Cytometry Assay. Apoptosis was demonstrated and quantified by flow cytometry analysis using an apoptosis kit (Cat. number KGA7073 Nanjing KeyGen Biotech Co.). MCF7 cells were seeded into 6 -well plates $\left(2 \times 10^{5} /\right.$ well). After treatment with SSCE $(0,160 \mu \mathrm{g} / \mathrm{ml})$ for $24 \mathrm{~h}$, MCF-7 cells were trypsinized by trypsin without EDTA, centrifuged at $1200 \mathrm{r}$ for $3 \mathrm{~min}$, washed twice with PBS, and stained with Annexin $\mathrm{V}$-fluorescein isothiocyanate (FITC) and propidium iodide (PI) according to the manufacturer's instructions. The cells were then filtered with a 300-mesh filter. Apoptotic cells were detected with a Beckman flow cytometry system (EPICS XL, Beckman) and analyzed with FlowJo 7.6.1 software (Tree Star). Each assay included at least 10,000 gated events. The early apoptotic cells are Annexin V-FITC positive and PI negative, while late apoptotic cells are Annexin V-FITC and PI doublepositive. Experiments were performed in triplicate.

The cell cycle was observed and quantified using propidium iodide (PI) staining for DNA by flow cytometry analysis. MCF-7 cells were seeded into 6 -well plates $\left(2 \times 10^{5} /\right.$ well $)$ with phenol red-free DMEM media and charcoal-stripped fetal bovine serum. In addition, the cells were treated with $10^{-8} \mathrm{M}$ E2 (as control), $10^{-8} \mathrm{M} \mathrm{E} 2$ and SSCE at the indicated 
concentration $(0,160$, and $320 \mu \mathrm{g} / \mathrm{ml}), 10^{-8} \mathrm{M} \mathrm{E} 2$ and $10^{-4} \mathrm{M}$ ICI182780, and DMEM without E2 for $24 \mathrm{~h}$. The cells were harvested and washed twice with ice-cold PBS. Cells were fixed in $70 \%$ ethanol overnight and washed once with PBS. After centrifugation at $1200 \mathrm{r}$ for $3 \mathrm{~min}$ and resuspension in $400 \mu \mathrm{l} \mathrm{PBS}$ with $50 \mu \mathrm{g} / \mathrm{ml}$ propidium iodide (PI) and $20 \mu \mathrm{g} / \mathrm{ml}$ RNase $\mathrm{A}$, the cells were incubated for $30 \mathrm{~min}$ at $37^{\circ} \mathrm{C}$ in the dark and filtered with a 300-mesh filter. PI fluorescence was detected using a Beckman flow cytometry system (EPICS XL, Beckman) and analyzed with FlowJo 7.6.1 software (Tree Star). Each assay included at least 10,000 gated events. Experiments were performed in triplicate.

2.6. Wound Healing Assays. Cells were seeded in 6-well tissue culture plates at $5 \times 10^{5}$ per well. When the cells grew into a monolayer, a scratch was created using a sterile p200 pipette. The scratch was created vertically in the middle of each well. The medium was removed, and the detached cells were removed by rinsing each well with $1 \mathrm{ml}$ PBS. Formation of the wound was confirmed by inverted light microscopy. After addition of phenol red-free serum-free media, the cells were then incubated with SSCE $(160 \mu \mathrm{g} / \mathrm{ml})$, estradiol $\left(10^{-8} \mathrm{M}\right)$, and $\operatorname{SSCE}(160 \mu \mathrm{g} / \mathrm{ml})+$ estradiol $\left(10^{-8} \mathrm{M}\right)$ and monitored by microscopic observation. Two vertical lines on each side of the scratch and one horizontal line, separating the wound in half, were placed with an indelible marker on the outside bottom of each well to ensure that the same field was identified during subsequent image acquisition. These markings served as reference points for photographic documentation. The change in the wound surface area was compared among groups over time. Digital photographic images were obtained at $0 \mathrm{~h}$ and $24 \mathrm{~h}$ using a motorized inverted microscope. Following the acquisition of all images, the surface area of each scratch was measured and outlined by two independent observers (blinded to the group situation) using Adobe Photoshop software. The surface area of each wounded region of the cell monolayer was then transformed into a square of equal surface area, and the linear mean length of each square was compared among groups. The rate of closure was quantified and compared between all groups for statistical analysis. Three replicate wells were used for each experimental condition. Experiments were performed in triplicate.

2.7. Western Blot Assay. MCF-7 cells were exposed to SSCE at the indicated concentration $(0,80,160$, and $320 \mu \mathrm{g} / \mathrm{ml})$ and incubated for $24 \mathrm{~h}$. The cells were washed once with PBS and collected. The cells were lysed for $30 \mathrm{~min}$ in lysis buffer (Beyotime, P0013K) containing cOmplete EDTA-free protease inhibitor (Roche, Cat. number 04693132001; 1 tablet suspended in $1 \mathrm{ml}$ ultrapure water and added 1:25 to the lysis buffer) and PhosSTOP (Roche, Cat. number 04906845001; 1 tablet suspended in $1 \mathrm{ml}$ ultrapure water and added 1:10 to lysis buffer). The lysates were subjected to shaking once every five min for the $30 \mathrm{~min}$ incubation. Then, the lysates were centrifuged at $12000 \mathrm{r}$ for $15 \mathrm{~min}$. The supernatants were transferred into new Eppendorf tubes, and the total protein was quantified. The samples were separated in a $10 \%$ gradient
SDS-PAGE (the proteins were separated in an $8 \%$ gradient SDS-PAGE for the detection of mTOR and p-mTOR) and transferred onto nitrocellulose membranes. The membrane was blocked using a blocking buffer (5\% milk, $20 \mathrm{mmol} / \mathrm{l}$ Tris$\mathrm{HCl}, \mathrm{pH} 7.6,150 \mathrm{mmol} / \mathrm{l} \mathrm{NaCl}$, and $0.1 \%$ Tween 20) at room temperature for $1.5 \mathrm{~h}$. The membranes were then incubated with antibodies against PCNA, ERK1/2, p-ERK1/2, PI3K, pPI3K, AKT, p-AKT, mTOR, p-mTOR, cytochrome C, Bax, Bcl-2, phosphorylated ER $\alpha$ (Ser118), phosphorylated ER $\beta$ (Ser105), and $\beta$-actin, followed by incubation with secondary antibodies. Densitometric analysis of the immunoblots was performed using an Odyssey infrared imaging system (LICOR Biosciences Company, USA). Experiments were performed in triplicate.

2.8. Dual-Luciferase Assay. MCF-7 cells were seeded into 24-well plates at the exponential phase of growth (approximately $2 \times 10^{5} /$ well) and cultured for $18-24 \mathrm{~h}$. Then, the serum containing medium was replaced by OPTI-MEM for transfection using Lipo2000 mixed with different plasmids, including 3X ERE TATA luc, pcDNA Flag ER beta, pEGFPC1-ER alpha, pFLAG-CMV2, pEGFP-C1, and the Firefly luciferase plasmid: pGL3-Basic Vector and pRL-TK Vector at a $2000: 1$ ratio (1 $\mu \mathrm{l}$ lipo2000:0.5 $\mathrm{g}$ plasmid). After $5 \mathrm{~h}$, the cells were changed from the transfection medium to the normal medium with serum. The cells were cultured for $24 \mathrm{~h}$ before addition of SSCE. After a12 h incubation, the cells were collected, counted, and seeded onto 96-well plates with each sample in 3 wells. The luciferase activity was detected following the instructions in the dual-luciferase assay kit (Vigorous, Cat \# T002). Briefly, the cells were washed with PBS, lysed in $30 \mu \mathrm{l} /$ well 1x Universal Lysis Buffer (ULB), gently shaken for $10 \mathrm{~min}$, and centrifuged at $1200 \mathrm{r}$ for $0.5 \mathrm{~min}$. The supernatants were placed in new Eppendorf tubes for luminescence detection. To detect the Firefly luciferase and the sea kidney luciferase, specific steps were carried out according to kit instructions.

2.9. Statistical Analysis. Data for cell proliferation were converted into percentages, where the values for the control condition were formulated as $100 \%$. All data were presented in comparison to controls. All experiments were performed in triplicate. Statistical significance of the difference was calculated using Student's $t$-test for paired data with the level of significance selected at $P<0.05$.

\section{Results}

SSCE inhibited the vitality of breast cancer MCF-7 cells both in the presence and in the absence of E2. We first examined the effect of different concentrations of E2 on the viability of ER+ MCF-7 cells using MTT assay and found that, at the concentration of $10^{-8} \mathrm{M} \mathrm{E2}$, the cells exhibited the highest viability with approximately $35 \%$ proliferation (data not shown). SSCE inhibited the proliferation of the MCF-7 cells in a dose-dependent manner (Figure 1(a)) with an estimated IC50 value of $109 \mu \mathrm{g} / \mathrm{ml}$ after $24 \mathrm{~h}$ incubation. In the presence of E2 at the concentration of $10^{-8} \mathrm{M}$, the effect of SSCE was 


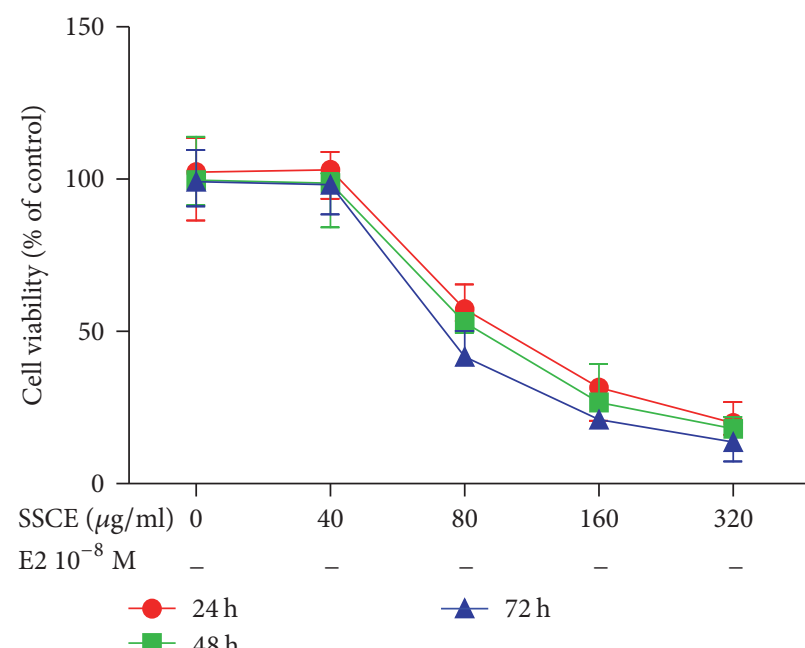

(a)

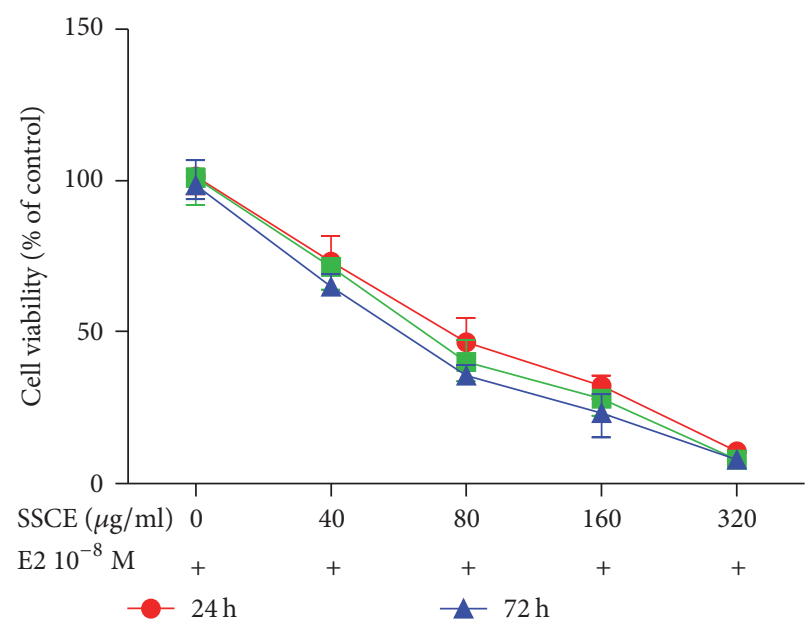

(b)

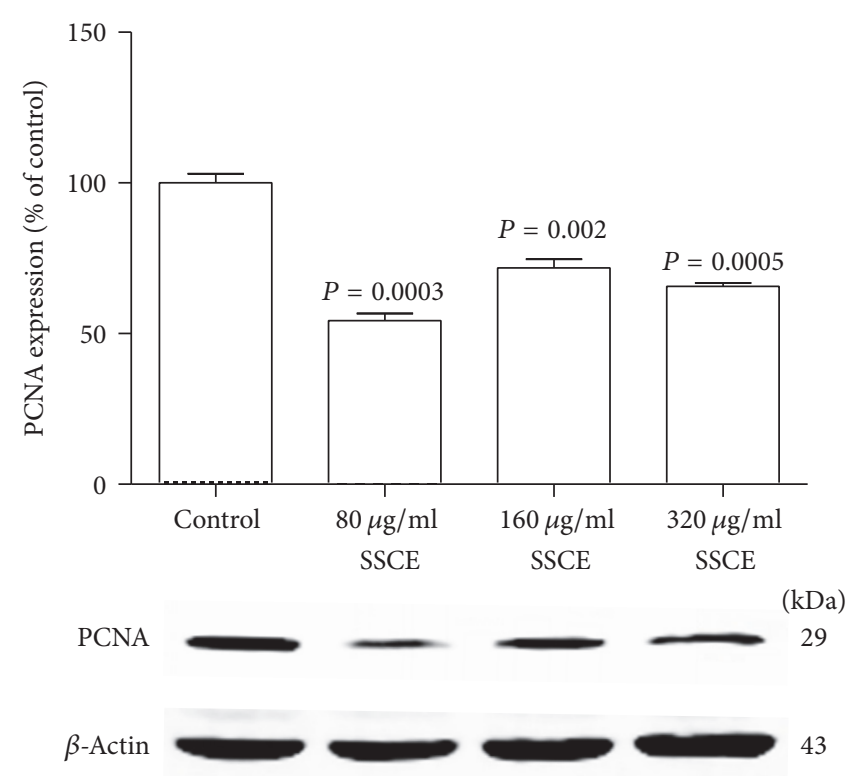

(c)

FIGURE 1: Inhibition of the viability of MCF-7 cells with SSCE treatment. (a) SSCE treatment in the absence of 17 $\beta$-estradiol (E2) inhibited the proliferation of MCF-7 cells. The IC50 of SSCE treated for $24 \mathrm{~h}, 48 \mathrm{~h}$, and $72 \mathrm{~h}$ was $109 \mu \mathrm{g} / \mathrm{ml}, 102 \mu \mathrm{g} / \mathrm{ml}$, and $83 \mu \mathrm{g} / \mathrm{ml}$, respectively. (b) Addition of $10^{-8} \mathrm{M}$ E2 promoted the effect of SSCE. The IC50 of SSCE in the presence of $10^{-8} \mathrm{M} \mathrm{E} 2 \mathrm{was} 81 \mu \mathrm{g} / \mathrm{ml}, 68 \mu \mathrm{g} / \mathrm{ml}$, and $60 \mu \mathrm{g} / \mathrm{ml}$ for a $24 \mathrm{~h}, 48 \mathrm{~h}$, and $72 \mathrm{~h}$ incubation, respectively. (c) The proliferation-related protein (PCNA) level was decreased upon treatment with SSCE $(80 \mu \mathrm{g} / \mathrm{ml}, 160 \mu \mathrm{g} / \mathrm{ml}$, and $320 \mu \mathrm{g} / \mathrm{ml})$ for $24 \mathrm{~h}$ compared to control.

enhanced (Figure 1(b)) with an IC50 value of $81 \mu \mathrm{g} / \mathrm{ml}$ after $24 \mathrm{~h}$ incubation. The inhibitory effect of SSCE was further demonstrated by the reduced level of the proliferation-related protein PCNA (Figure 1(c)).

3.1. SSCE Triggered Apoptosis of MCF-7 Cells. Apoptotic cells identified by a flow cytometry assay were significantly increased in the MCF-7 cells treated with SSCE at the concentration of $160 \mu \mathrm{g} / \mathrm{ml}$ for $24 \mathrm{~h}$. Both early apoptotic cells and late apoptotic cells were increased and the differences compared to the control group were statistically significant (Figure 2(a)). Then, we assessed the apoptotic related proteins cytochrome $\mathrm{C}, \mathrm{Bax}$, and $\mathrm{Bcl}-2$ by Western blot analysis. It showed that SSCE $(80 \mu \mathrm{g} / \mathrm{ml}, 160 \mu \mathrm{g} / \mathrm{ml}$, and $320 \mu \mathrm{g} / \mathrm{ml})$ upregulated the levels of cytochrome $\mathrm{C}$ and Bax and downregulated the level of Bcl-2 (Figure 2(b)).

3.2. SSCE Triggered a G0/G1 Phase Arrest of MCF-7 Cells. We analyzed the cell cycle of the MCF-7 cells cultured under different concentrations of SSCE $(80 \mu \mathrm{g} / \mathrm{ml}, 160 \mu \mathrm{g} / \mathrm{ml}$, and $320 \mu \mathrm{g} / \mathrm{ml}$ ) in the presence of $10^{-8} \mathrm{M} \mathrm{E} 2$ for $24 \mathrm{~h}$. The flow cytometry results showed that SSCE treatment induced a dose-dependent accumulation of cells arresting in the G0/G1 phase, with a reduction in the proportion of cells in the $S$ 

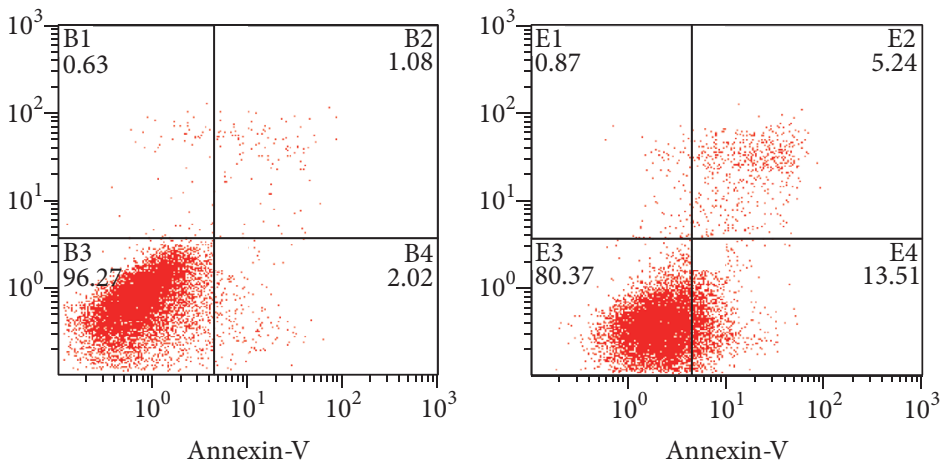

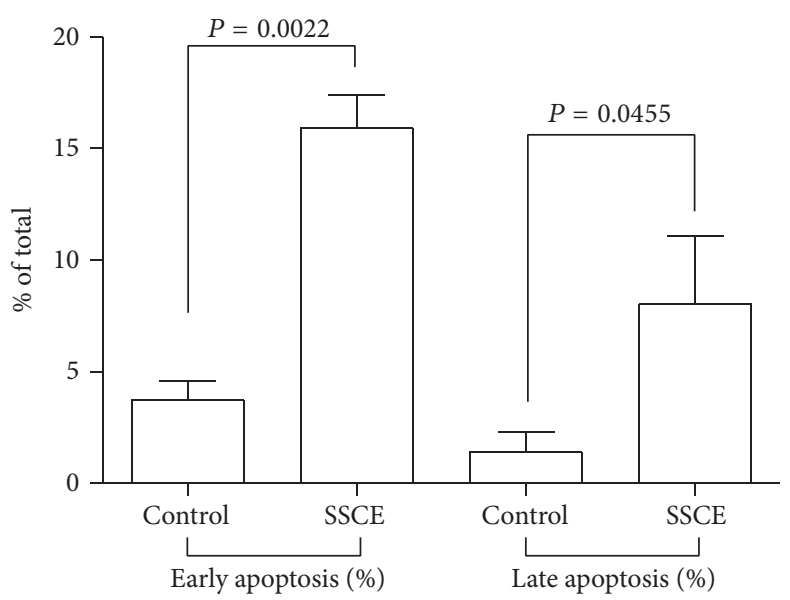

(a)
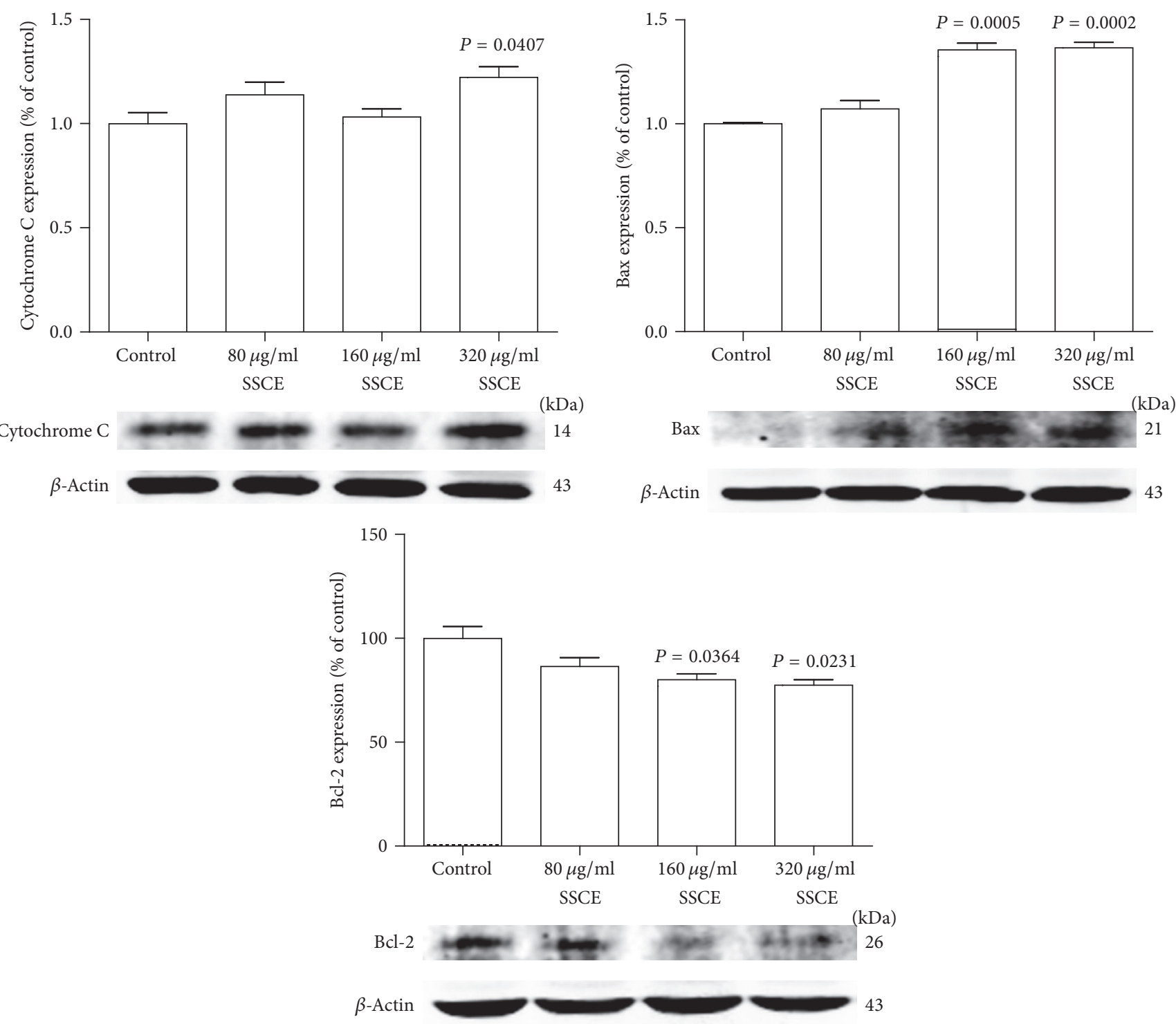

(b)

FIGURE 2: (a) SSCE $(160 \mu \mathrm{g} / \mathrm{ml})$ treatment for $24 \mathrm{~h}$ induced apoptosis of MCF-7 cells with a significant increase in the proportion of both early and late apoptotic cells analyzed by FACS. (b) Western blot analysis and quantification of the band intensity show that after SSCE ( $80 \mu \mathrm{g} / \mathrm{ml}$, $160 \mu \mathrm{g} / \mathrm{ml}$, and $320 \mu \mathrm{g} / \mathrm{ml}$ ) treatment for $24 \mathrm{~h}$, the expression levels of apoptosis-related proteins cytochrome C and Bax were elevated, and Bcl-2 expression was suppressed. 

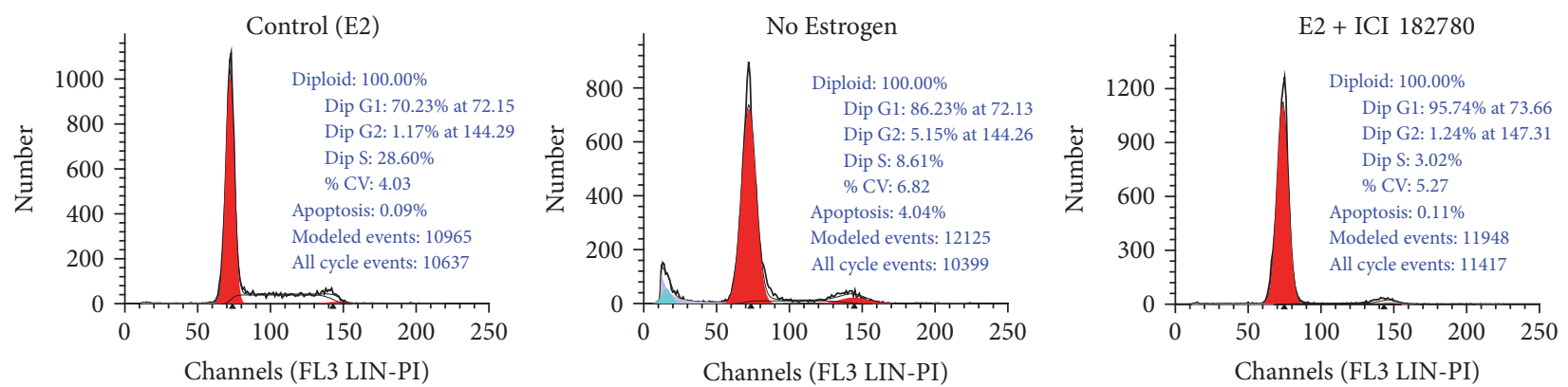

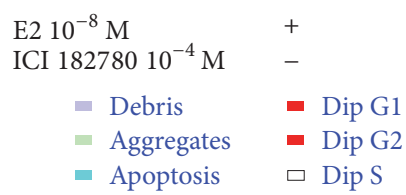

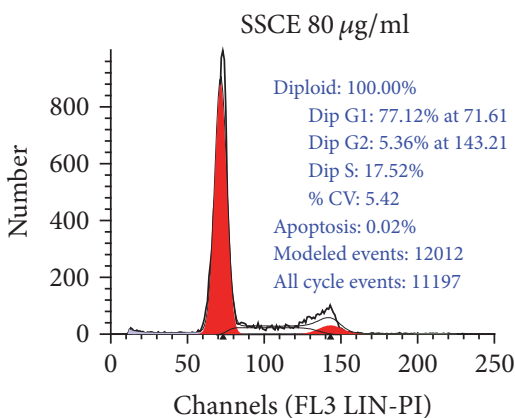

$$
\begin{aligned}
& \text { E2 } 10^{-8} \mathrm{M}
\end{aligned}
$$

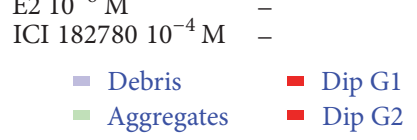

$$
\begin{aligned}
& \text { - Apoptosis } \square \text { Dip S }
\end{aligned}
$$

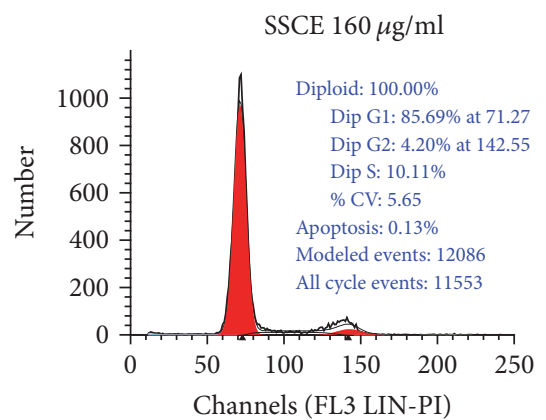

$$
\begin{aligned}
& \begin{array}{l}
\text { E2 } 10^{-8} \mathrm{M} \\
\text { ICI } 18278010^{-4} \mathrm{M}+
\end{array} \\
& \text { - Aggregates } \\
& \text { - Dip G1 } \\
& \text { - Apoptosis } \\
& \text { - Dip G2 }
\end{aligned}
$$

SSCE $320 \mu \mathrm{g} / \mathrm{ml}$

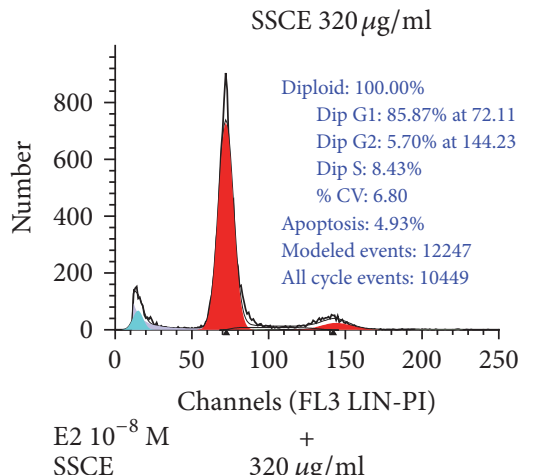

$$
\begin{aligned}
& \begin{array}{lc}
\text { E2 } 10^{-8} \mathrm{M} & + \\
\text { SSCE } & 160 \mu \mathrm{g} / \mathrm{ml}
\end{array} \\
& \text { - Debris = Dip G1 } \\
& \text { - Aggregates - Dip G2 } \\
& \text { - Apoptosis } \square \text { Dip S }
\end{aligned}
$$

$$
\begin{array}{ll}
=\text { Debris } & =\text { Dip G1 } \\
=\text { Aggregates } & =\text { Dip G2 } \\
=\text { Apoptosis } & \square \text { Dip S }
\end{array}
$$
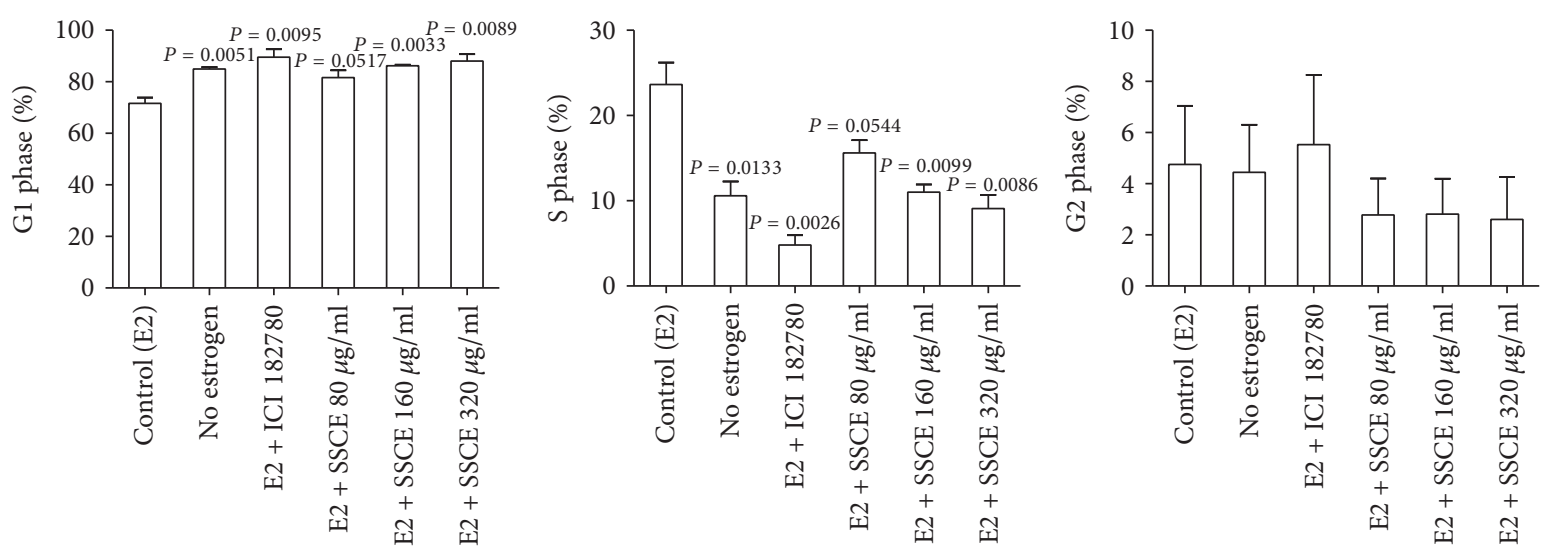

FIGURE 3: The control groups included MCF-7 cells cultured in DMEM with $10^{-8} \mathrm{M}$ E2 and cells cultured in the absence of E2. When treated with SSCE $(80 \mu \mathrm{g} / \mathrm{ml}, 160 \mu \mathrm{g} / \mathrm{ml}$, and $320 \mu \mathrm{g} / \mathrm{ml})$ in the presence of $10^{-8} \mathrm{M} \mathrm{E2}$, the proportion of cells in the G1 phase of the cell cycle was exacerbated. The proportion of cells in the S phase was reduced in SSCE treated groups. There was no difference in the proportion of cells in the G2 phase between these groups. The cells were cultured in phenol red-free DMEM with charcoal-stripped FBS.

phase. Similar results were obtained for the cells cultured in the presence of ICI182780 $\left(10^{-4} \mathrm{M}\right)+\mathrm{E} 2\left(10^{-8} \mathrm{M}\right)$ or in the absence of E2 (the no-estrogen cultured group) (Figure 3).

3.3. SSCE Inhibited the Migration of MCF-7 Cells. Wound healing assays were used to assess the effect of SSCE on the invasion and migration ability of MCF-7 cells. The images of the scratches were documented at 0 and $24 \mathrm{~h}$ after the wounding (Figure 4(a)), and the closure of the wound was measured (Figure 4(b)). The healing assay indicated that, compared to the MCF-7 culture with no estrogen, $\mathrm{E}_{2}\left(10^{-8} \mathrm{M}\right)$ enhanced the invasion and migration of MCF-7 cells and 

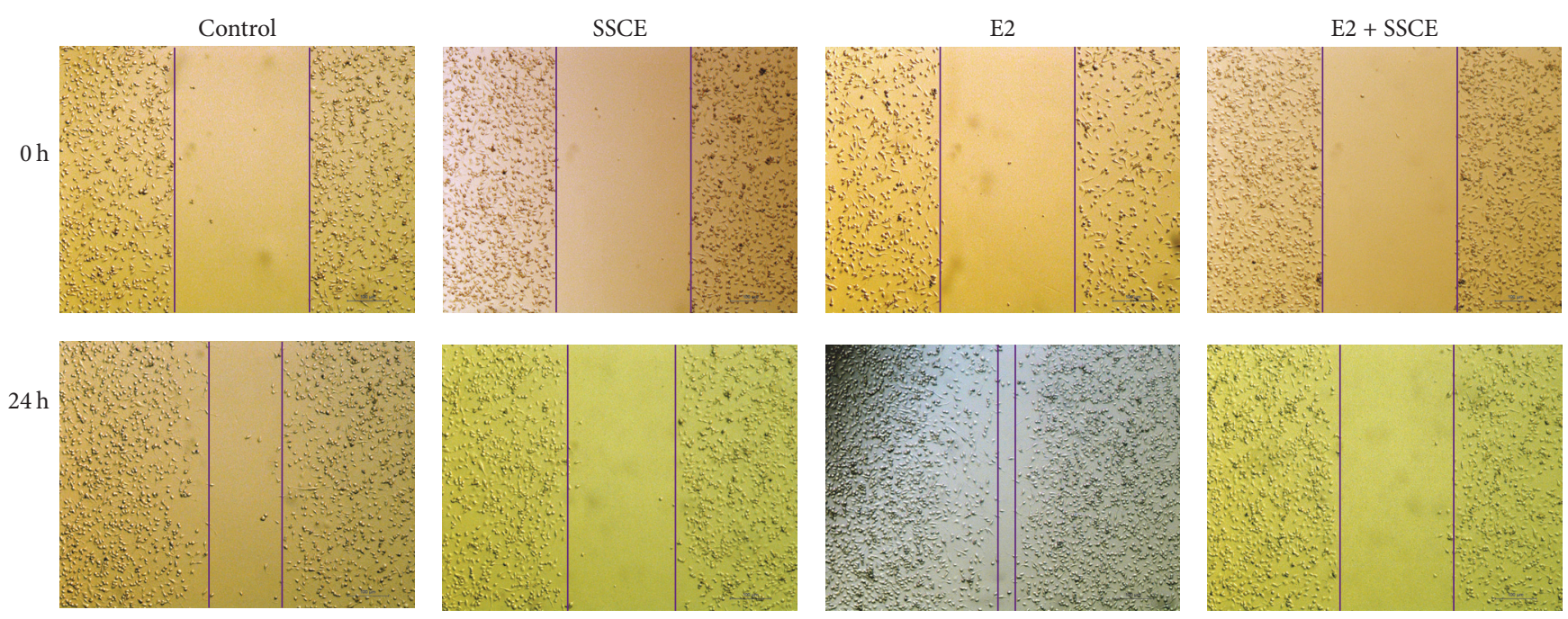

(a)
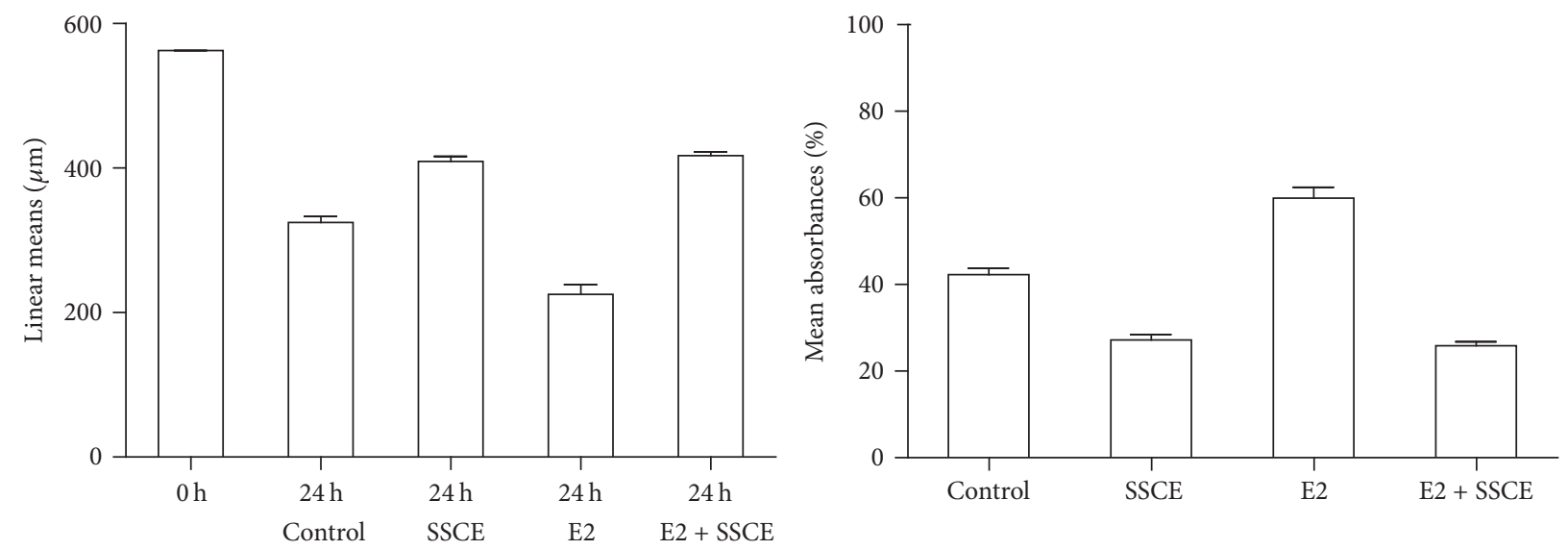

(b)

FIGURE 4: Wound healing assays to assess the effect of SSCE on migration ability. MCF-7 cells were cultured in a 6-well plate to approximately $90 \%$ confluency. A wound was generated by a scratch in the middle of the plate using a pipette. The wound closure was measured upon treatment with E2 $\left(10^{-8} \mathrm{M}\right)$ and SSCE $(160 \mathrm{mg} / \mathrm{ml})$ alone or E2 $\left(10^{-8} \mathrm{M}\right)+$ SSCE $(160 \mathrm{mg} / \mathrm{ml})$ for $24 \mathrm{~h}$. (a) Representative images show the wound at 0 and $24 \mathrm{~h}$. The migration of MCF-7 cells was promoted by E2 and inhibited by SSCE both in the presence and absence of E2. (b) The linear mean length and the confidence interval for each wounded area $24 \mathrm{~h}$ after the scratch are presented and compared to $0 \mathrm{~h}$. The linear mean length of the control and the cells treated with SSCE and SSCE + E2 were significantly reduced compared to that in the other groups $(P<0.001)$. There was a significant difference noted in the linear means between the control and the E2-treated cells $(P<0.001)$. The rate of closure with the condition interval for each group $24 \mathrm{~h}$ after scratch is presented. The rates of closure of the SSCE group and SSCE + E2 group were significantly lower than that in the other groups.

SSCE $(160 \mu \mathrm{g} / \mathrm{ml})$ significantly suppressed the invasion and migration of MCF-7 cells both in the presence and in the absence of $\mathrm{E}_{2}\left(10^{-8} \mathrm{M}\right)$ (Figure 4$)$.

3.4. SSCE Inhibited the Activity of the Estrogen Receptor (ERE). The cells were transiently transfected with the constructs as described in the Material and Methods section. The activity of intranuclear p-ER activity was detected using a dual-luciferase reporter system. The activity of $\mathrm{p}-\mathrm{ER} \alpha$ and $\mathrm{p}-\mathrm{Er} \beta$ in MCF-7 cells cultivated in the medium without estrogen is shown in Figure 5(a). The luciferase activity in p$\mathrm{ER} \alpha$ and $\mathrm{p}-\mathrm{ER} \beta$ is higher than that in the ERE-transfected cells. SSCE $(80 \mu \mathrm{g} / \mathrm{ml}, 160 \mu \mathrm{g} / \mathrm{ml}$, or $320 \mu \mathrm{g} / \mathrm{ml})$ treatment for $12 \mathrm{~h}$ attenuated the luciferase activity in the p-ER $\alpha$ - and $\mathrm{p}$ $\mathrm{ER} \beta$-transfected cells, especially in the group treated with $160 \mu \mathrm{g} / \mathrm{ml} \mathrm{SSCE}$ (Figure 5(a)).

Expression of the receptors was analyzed by Western blot. The control group exhibited a strong phosphoestrogen receptor $\alpha$ (Ser118) protein band that was reduced in the cells cultured in the presence of SSCE $(80 \mu \mathrm{g} / \mathrm{ml}, 160 \mu \mathrm{g} / \mathrm{ml}$, or $320 \mu \mathrm{g} / \mathrm{ml}$ ) for $24 \mathrm{~h}$. Inhibition of expression of the receptors by SSCE was dose dependent (Figure 5(b)). In contrast, SSCE treatment did not affect the expression of phosphoestrogen receptor $\beta$ (Ser105) (Figure 5(b)). 

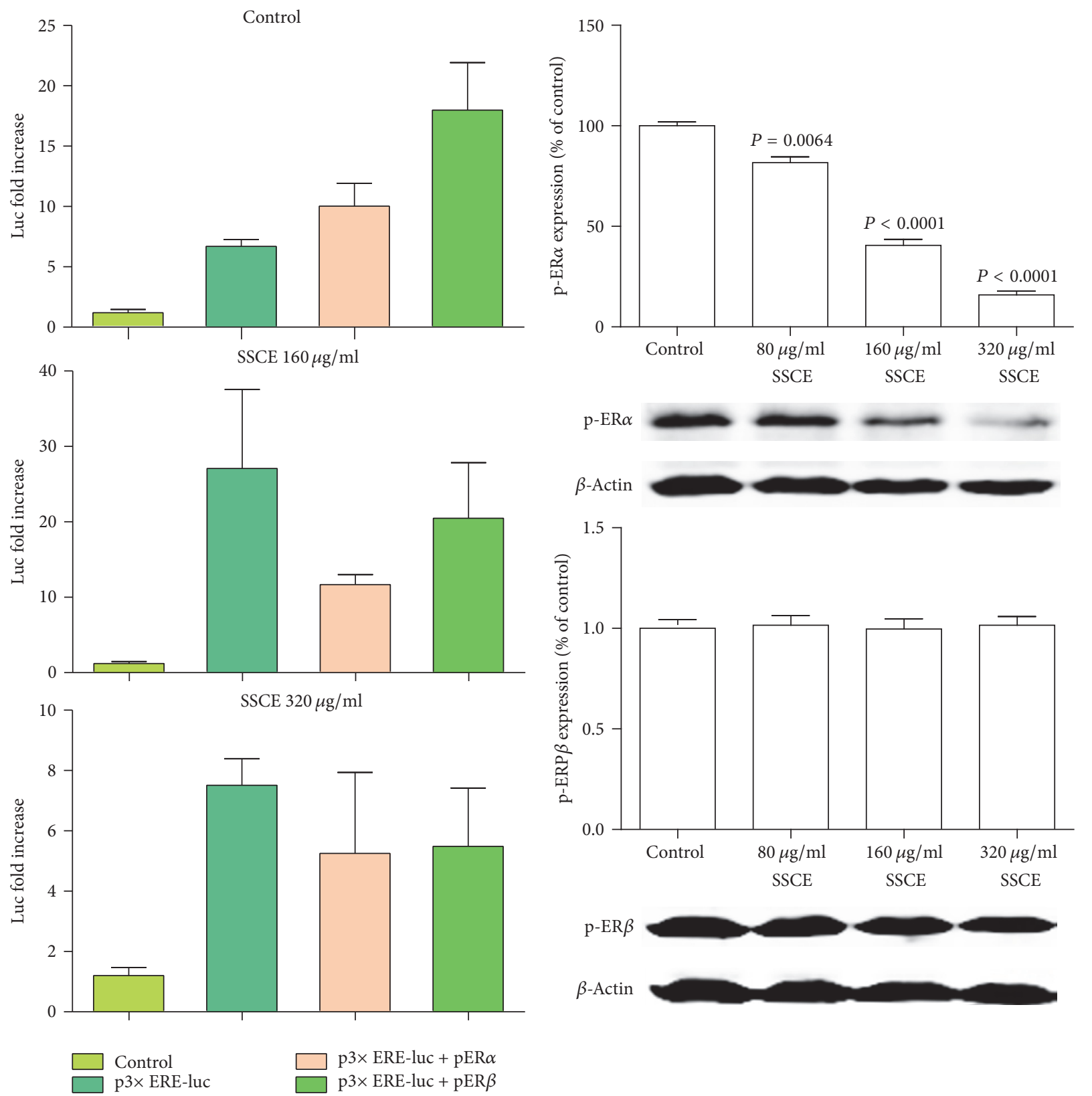

(a)

(b)

FIgure 5: (a) The activity of nucleus ERE, p-ER $\alpha$, and p-ER $\beta$ in MCF-7 cells cultured without estrogen detected by a double-fluorescence enzyme reporting system is shown. Relative to ERE, the activation of $\mathrm{p}-\mathrm{ER} \alpha$ and $\mathrm{p}-\mathrm{ER} \beta$ in the control group was significantly higher than that in MCF-7 cells cultured with SSCE $(160 \mu \mathrm{g} / \mathrm{ml}$ and $320 \mu \mathrm{g} / \mathrm{ml})$ for $12 \mathrm{~h}$. (b) p-ER $\alpha$ and p-ER $\beta$ protein levels after treatment with SSCE $(80 \mu \mathrm{g} / \mathrm{ml}, 160 \mu \mathrm{g} / \mathrm{ml}$, and $320 \mu \mathrm{g} / \mathrm{ml})$ cultured for $24 \mathrm{~h}$ were detected by Western blot. SSCE inhibited p-ER $\alpha$ expression in a concentrationdependent manner. However, SSCE did not affect the expression of $\mathrm{p}-\mathrm{ER} \beta$.

3.5. SSCE Regulated the MAPK Signaling Pathway. Finally, we investigated the typical protein signaling events in the MAPK PI3K/AKT pathway by Western blot to determine whether SSCE affected the protein expression. The expression levels of ERK1/2, p-ERK1/2, AKT, p-AKT, p-mTOR, PI3K, and p-PI3K were significantly reduced in the MCF-7 cells treated with SSCE in a concentration-dependent manner. In comparison, there was no significant difference in the expression of mTOR between the different concentrations of SSCE (Figure 6).

\section{Discussion}

Earlier studies reported that Spatholobi Caulis extract inhibited proliferation of KB, K562, and HL60 cells with an IC50 

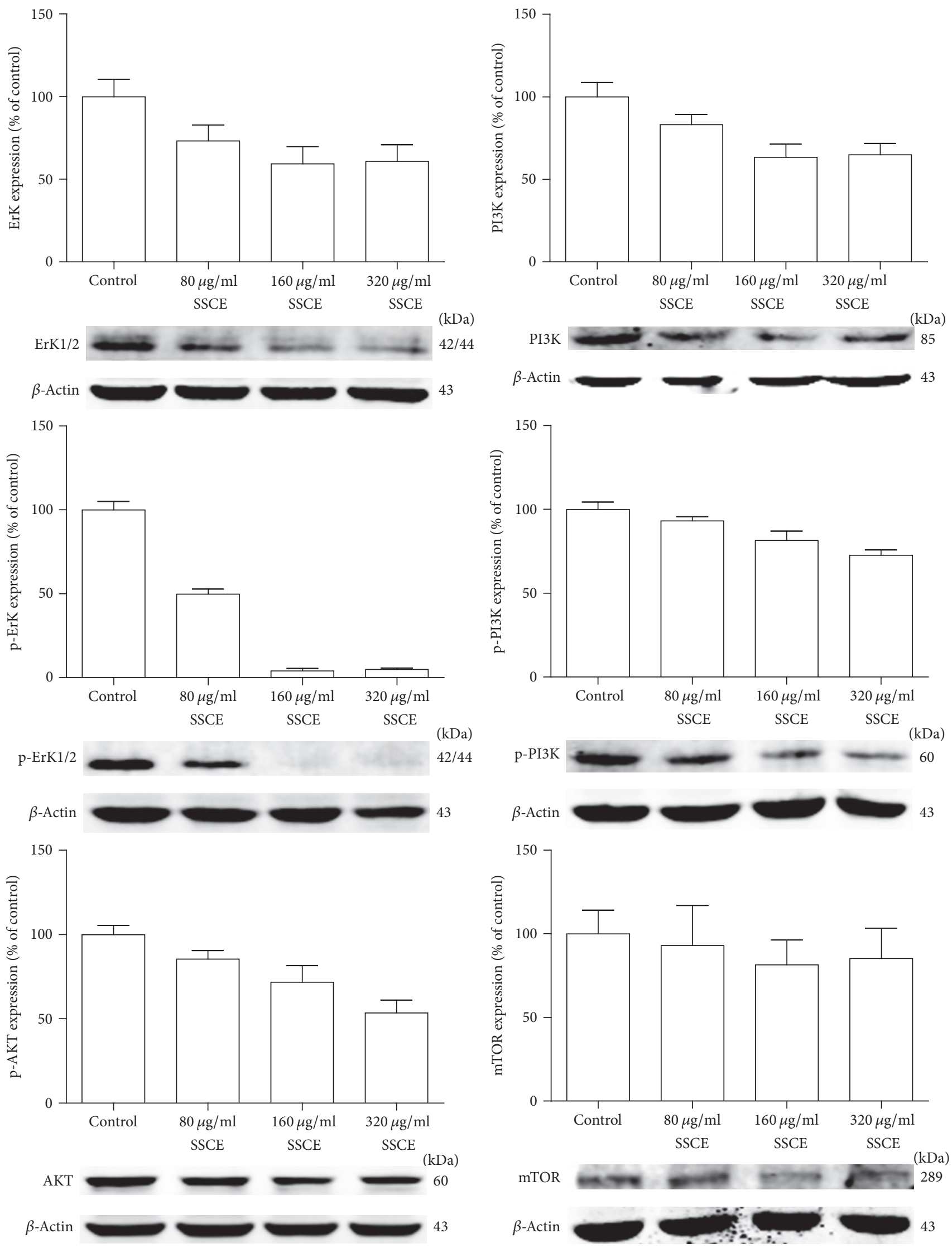

FIgURE 6: Continued. 

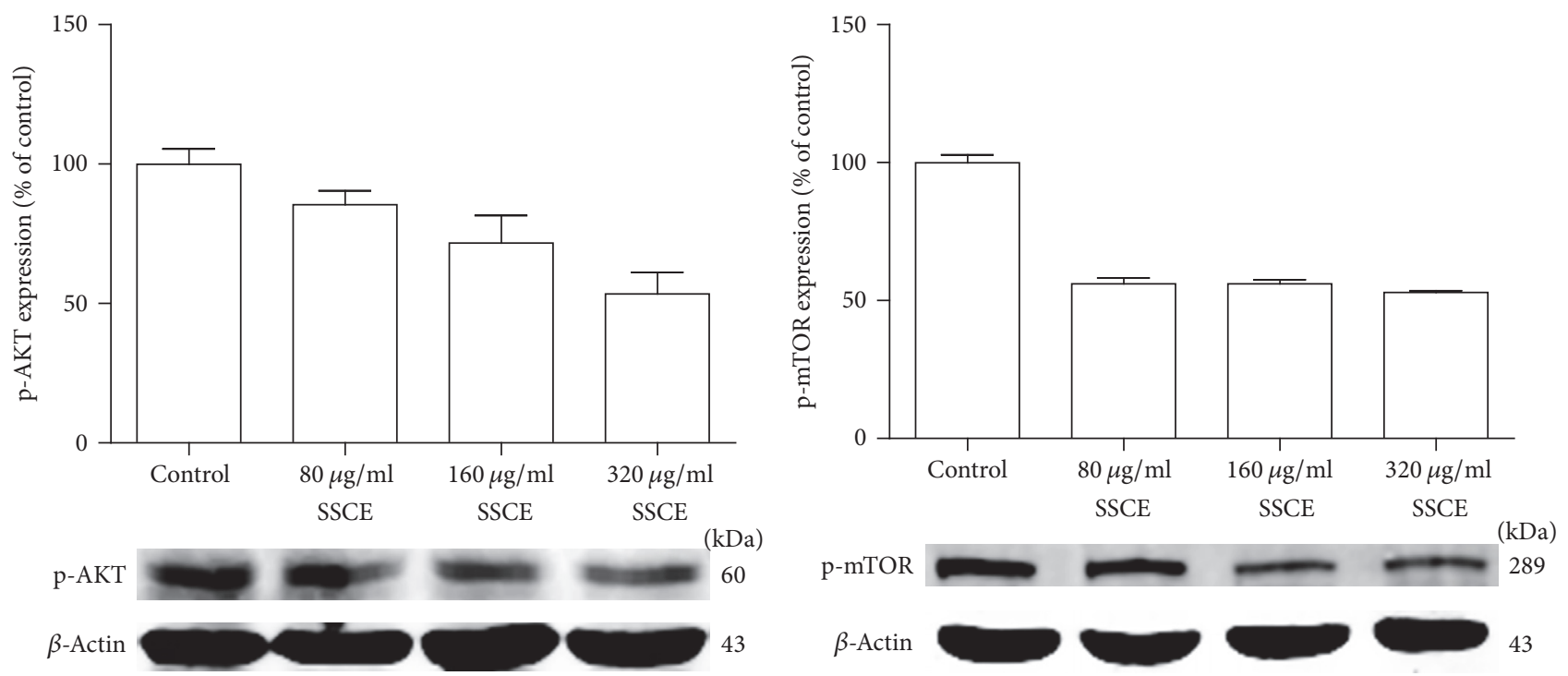

FIGURE 6: Western blot analysis showing that expression levels of ERK1/2, p-ERK1/2, AKT, p-AKT, PI3K, p-PI3K, and p-mTOR were significantly inhibited in the MCF-7 cells treated with SSCE $(80 \mu \mathrm{g} / \mathrm{ml}, 160 \mu \mathrm{g} / \mathrm{ml}$, and $320 \mu \mathrm{g} / \mathrm{ml})$ in a concentration-dependent manner. The expression of mTOR had no obvious association with the SSCE concentration.

value of 17.6, 8.3, and $9.7 \mathrm{mg} / \mathrm{ml}$, respectively [11]. Spatholobi Caulis was also demonstrated to inhibit platelet aggregation induced by B16BL6 melanoma cells with an IC50 of $50 \mathrm{mg} / \mathrm{ml}$. It also inhibited HT1080 cancer cell invasion through a Matrigel-coated filter with an IC50 of $25 \mathrm{mg} / \mathrm{ml}$ [12]. SSCE was also found to induce apoptosis via the caspase-dependent pathway in U937 cells [13]. In line with the previous reports, we found similar antiproliferation effect of Spatholobi Caulis extract (SSCE) in MCF-7 cells with an IC50 value of $109 \mu \mathrm{g} / \mathrm{ml}$. SSCE treatment resulted in inhibition of MCF-7 migration as observed in a scratch test, induced apoptosis, and arrested the cell cycle at the G0/G1 phase.

Estrogens are suggested to trigger breast cancer by stimulating cell proliferation through receptor-mediated processes and by way of their toxic metabolites [14, 15]. A 15-year randomized, placebo-controlled trial involving 161808 postmenopausal women revealed that long-term use of hormone replacement therapy (HRT) is associated with an increased risk of breast cancer [16]. Thus, steroidal was added to the list of known human carcinogens in the US in 2001 [17]. Spatholobi Caulis is wildly used for the treatment of ER+ mammary tumor patients in China. The main components of Spatholobus suberectus column extract (SSCE) from Spatholobi Caulis, analyzed by HPLC [18], include formononetin, genistein, calycosin, and daidzein, all of which are flavonoid phytoestrogens [18]. Phytoestrogens are biologically active compounds of plant origin that structurally mimic the mammalian steroid hormone $17 \beta$-estradiol (E2) and are mainly found in vegetables, fruits, and herbs [19]. Phytoestrogens bind with estrogen receptors and may modulate estrogen receptor activity [20,21]. Studies have shown that women in the US have a three times higher risk for breast cancer than Asian women [22]. This difference has been partially associated with Asian diets that consist of a considerably large proportion of phytoestrogens [20, 21]. Some phytoestrogens can reduce the carcinogenic effect of bisphenol A by blocking the connection of bisphenol A and ER [23, 24]. Epidemiologic and experimental evidence suggest that phytoestrogens play a chemopreventive role in breast cancers. Our findings provided further biological evidence for the effect of phytoestrogen-type molecules in treatment of breast cancer.

There are two main pathways by which $\mathrm{E} 2$ plays its role. In the classical pathway, E2 diffuses into the nucleus and binds to the ER. Once activated by E2, the ER is able to be phosphorylated and translocates into the nucleus where it binds to specific sequences of DNA known as estrogen response elements (ERE) [25]. The DNA receptor complex then recruits other proteins that are responsible for the transcription of downstream DNA into mRNA and finally protein that results in a change in cell function. In addition, activated ER also interacts with activator protein 1 (AP-1) and transcription factor specificity protein $1(\mathrm{Sp}-1)$ to promote transcription via several coactivators such as PELP1 [25]. AP-1 activity can be regulated by the ERK pathway. This results in activated cjun and its downstream targets such as RACK1 and cyclin D1 [26]. Cyclin D1 is required for the progression through the G1 phase of the cell cycle to the $S$ phase and reduced cyclin D1 expression results in G1 arrest [27]. c-Jun is overexpressed in MCF-7 cells [28]. c-Jun can also protect cells from apoptosis [27] (Figure 7).

The activity of nucleus $\mathrm{p}-\mathrm{ER} \alpha$ and $\mathrm{p}-\mathrm{ER} \beta$ was suppressed by SSCE. SSCE may affect the activation of $E R \alpha$, decreasing $\mathrm{p}$ $\mathrm{ER} \alpha$. Inactivated ER cannot bind to ERE, preventing the transcription and translation of ERE and resulting in arrest of the cell cycle. It has been reported that phosphorylation of S105 $\operatorname{ER} \beta$ in breast cancer is associated with improved survival. Even in endocrine-resistant breast tumors, S105-ER $\beta$ might be a useful additional prognostic marker [29]. Low S118 and 


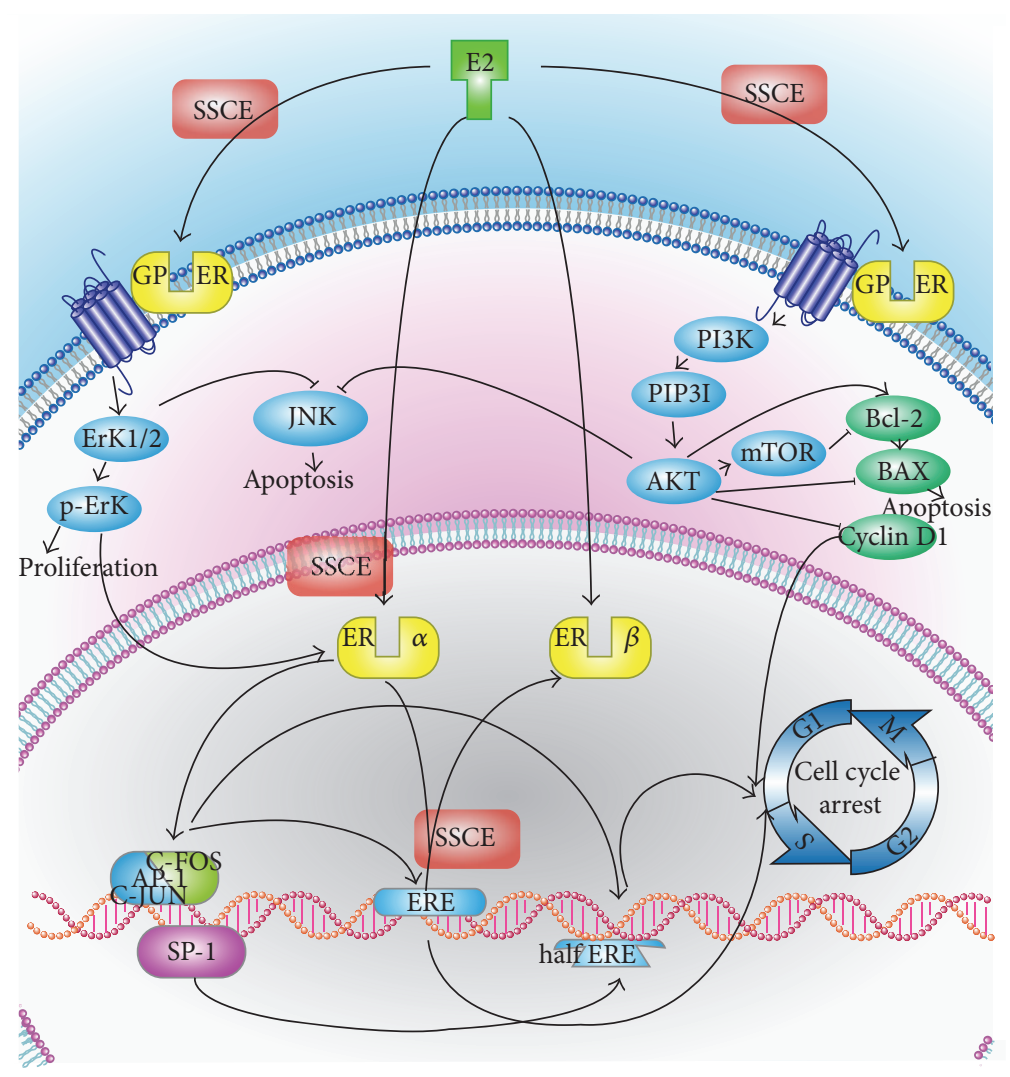

FIGURE 7: The classic mechanism for E2 action is E2 diffusing into the nucleus, binding to the nucleus estrogen receptor (ER), combining with ERE on DNA, starting transcription translation and inducing the cycle of multiplication in cancer cells. In addition, activated ER $\alpha$ can activate AP-1 and SP-1, which are transcription enhancers that can promote the transcription translation of ERE and enable incomplete ERE (half ERE) to transcribe and translate. SSCE may affect the activation of ER $\alpha$, decreasing p-ER $\alpha$, reducing the combination ability of ER and ERE, and stopping ERE from transcribing and translating. On the other hand, E2 can combine with GPER on the cell membrane, increase the expression of ERK, promote cell proliferation, activate the PI3K-AKT pathway, increase the activation of mTOR and the upregulation of Bcl-2 and cyclin D, downregulate Bax, reduce apoptosis, and start the cell cycle. Both ERK and AKT can inhibit JNK, reducing apoptosis. SSCE may downregulate the PI3K-AKT, ERK pathway by GPER, resulting in a downregulation of Bcl-2, upregulation of Bax, reduction in the inhibition of JNK, promotion of cell apoptosis, and downregulation of cyclin D, thereby blocking the cell cycle.

high S167 ER-phosphorylation are associated with a diseasefree state and overall survival [30]. In the same line, our results show that SSCE treatment attenuated p-ER $\alpha$ (S118) expression but did not affect expression of p-ER $\beta$ (S105).

The second pathway of $\mathrm{E} 2$ is through binding to G protein-coupled ER on the cell membrane [31], increasing expression activity of ERK and activating the PI3K-AKT pathway [32]. As the mitogen-activated protein kinase (MAPK) cascades are major signaling transduction molecules in apoptosis [33] and MAPK signaling pathways have been identified as chemotherapeutic targets for sensitizing cancer cells to apoptosis [34], the reduction of ERK and p-ERK protein expression by SSCE treatment may have contributed to the inhibitory effect on the proliferation of the tumor cells. Further, the PI3K/AKT signal transduction pathway plays a pivotal role in cell survival and prevents cancer cells from apoptosis during tumorigenesis [35]. This is also in agreement with our findings that SSCE impaired the expression of AKT, p-AKT, PI3K, p-PI3K, and p-mTOR, repressing the
$\mathrm{PI} 3 \mathrm{~K} / \mathrm{AKT}$ pathway, downregulating $\mathrm{Bcl}-2$, and upregulating Bax, which consequently induced cell cycle arrest and apoptosis. It appeared that SSCE downregulated the PI3KAKT, ERK pathway by GPER; however, we cannot rule out whether SSCE has affected expression of other pathways, as it was reported that inhibition of ER signaling by tamoxifen enhanced HER2 expression [36].

\section{Conclusion}

In conclusion, our results showed that the Spatholobus suberectus column extract (SSCE) induced apoptotic cell cycle arrest of MCF-7 cells, inhibited activity of nucleus p-ER $\alpha$ and $\mathrm{p}-\mathrm{ER} \beta$, and downregulated the expression of $\mathrm{p}-\mathrm{ER} \alpha$, which resulted in suppression of the MAPK PI3K/AKT pathway. The results indicate that the herbal extract inhibited the proliferation of ER-positive MCF-7 cells, contributing to the suppression of ER activity. Our data support the use of Spatholobi 
Caulis as a complementary medicine for management of breast cancer patients.

\section{Competing Interests}

The authors declare that there are no competing interests.

\section{Acknowledgments}

This study was funded by Beijing Natural Science Foundation (7122083), National Natural Science Foundation of China (nos. 81673924 and 81373815), Specialized Research Fund for the Doctoral Program of Higher Education of China (20131107110014), National Natural Science Foundation of Beijing (7162084), Beijing Municipal Education Commission (KM201510025025), and Beijing Municipal Administration of Hospitals' Youth Programme (code QML20150903).

\section{References}

[1] L. A. Torre, F. Bray, R. L. Siegel, J. Ferlay, J. Lortet-Tieulent, and A. Jemal, “Global cancer statistics, 2012," CA: A Cancer Journal for Clinicians, vol. 65, no. 2, pp. 87-108, 2015.

[2] R. L. Theriault, R. W. Carlson, C. Allred et al., "Breast cancer, version 3.2013: featured updates to the NCCN guidelines," Journal of the National Comprehensive Cancer Network, vol. 11, no. 7, pp. 753-761, 2013.

[3] T. De Marchi, J. A. Foekens, A. Umar, and J. W. Martens, "Endocrine therapy resistance in estrogen receptor (ER)-positive breast cancer," Drug Discovery Today, vol. 21, no. 7, pp. 1181-1188, 2016.

[4] S. Zhang and L. Xuan, "New phenolic constituents from the stems of Spatholobus suberectus," Helvetica Chimica Acta, vol. 89, no. 6, pp. 1241-1245, 2006.

[5] E.-Y. Su, Y.-H. Fang, and H.-S. Chen, "Clinical observation of treating 62 patients with severe aplastic anemia failing in immunosuppressive therapy by integrative medicine," Zhongguo Zhong Xi Yi Jie He Za Zhi, vol. 32, no. 12, pp. 1616-1620, 2012.

[6] Chinese Pharmacopoeia, China Medical Science Press, Beijing, China, 2010.

[7] M.-H. Lee, Y.-P. Lin, F.-L. Hsu, G.-R. Zhan, and K.-Y. Yen, "Bioactive constituents of Spatholobus suberectus in regulating tyrosinase-related proteins and mRNA in HEMn cells," Phytochemistry, vol. 67, no. 12, pp. 1262-1270, 2006.

[8] T. Fleischer, T. Chang, J. Chiang, C. Chang, C. Hsieh, and H. Yen, "Adjunctive Chinese Herbal Medicine therapy improves survival of patients with chronic myeloid leukemia: a nationwide population-based cohort study," Cancer Medicine, vol. 5, no. 4, pp. 640-648, 2016.

[9] Y. Fu, Y. Cheng, J.-P. Chen, and D.-M. Wang, "Advances in studies on chemical constituents in Spatholobi Caulis and their pharmacological activities," Chinese Traditional and Herbal Drugs, vol. 42, no. 6, pp. 1229-1234, 2011.

[10] H. Hatcher, R. Planalp, J. Cho, F. M. Torti, and S. V. Torti, "Curcumin: from ancient medicine to current clinical trials," Cellular and Molecular Life Sciences, vol. 65, no. 11, pp. 1631-1652, 2008.

[11] D. Lu, H. He, B. Wu, and S. Yao, "Cytotoxic effect on cancer cells and structural identification of phenols from Spatholobi caulis by HPLC-ESI-MS(n)," Natural Product Communications, vol. 4, no. 6, pp. 809-812, 2009.
[12] B.-J. Lee, I.-Y. Jo, Y. Bu et al., "Antiplatelet effects of Spatholobus suberectus via inhibition of the glycoprotein IIb/IIIa receptor," Journal of Ethnopharmacology, vol. 134, no. 2, pp. 460-467, 2011.

[13] E.-S. Ha, E.-O. Lee, T.-J. Yoon et al., "Methylene chloride fraction of Spatholobi Caulis induces apoptosis via caspase dependent pathway in U937 cells," Biological \& Pharmaceutical Bulletin, vol. 27, no. 9, pp. 1348-1352, 2004.

[14] J. D. Yager and N. E. Davidson, "Estrogen carcinogenesis in breast cancer," The New England Journal of Medicine, vol. 354, no. 3, pp. 270-282, 2006.

[15] E. L. Cavalieri, D. E. Stack, P. D. Devanesan et al., "Molecular origin of cancer: catechol estrogen-3,4-quinones as endogenous tumor initiators," Proceedings of the National Academy of Sciences of the United States of America, vol. 94, no. 20, pp. 1093710942, 1997.

[16] W. Horst-Sikorska and A. Wawrzyniak, "The role of hormonal therapy in osteoporosis," Endokrynologia Polska, vol. 62, no. 1, pp. 61-64, 2011.

[17] L. N. Petz, Y. S. Ziegler, M. A. Loven, and A. M. Nardulli, "Estrogen receptor $\alpha$ and activating protein-1 mediate estrogen responsiveness of the progesterone receptor gene in MCF-7 breast cancer cells," Endocrinology, vol. 143, no. 12, pp. 4583-4591, 2002.

[18] H. Wang, Y. Liu, Z. Zenc, and W. He, "Study on HPLC chromatographic fingerprint of anti-tumor active site SSCE of Caulis spatholobi," Zhongguo Zhongyao Zazhi, vol. 36, no. 18, pp. 25252529, 2011.

[19] C. R. Sirtori, A. Arnoldi, and S. K. Johnson, "Phytoestrogens: end of a tale?" Annals of Medicine, vol. 37, no. 6, pp. 423-438, 2005.

[20] S. M. Mense, F. Remotti, A. Bhan et al., "Estrogen-induced breast cancer: alterations in breast morphology and oxidative stress as a function of estrogen exposure," Toxicology and Applied Pharmacology, vol. 232, no. 1, pp. 78-85, 2008.

[21] H. Adlercreutz, "Phytoestrogens and breast cancer," Journal of Steroid Biochemistry and Molecular Biology, vol. 83, no. 1-5, pp. 113-118, 2002.

[22] G. Ursin, L. Bernstein, and M. C. Pike, "Breast cancer," Cancer Surveys, vol. 19-20, pp. 241-264, 1994.

[23] B. D. Bernardo, J. Z. Brandt, T. F. Grassi, L. T. R. Silveira, W. R. Scarano, and L. F. Barbisan, "Genistein reduces the noxious effects of in utero bisphenol A exposure on the rat prostate gland at weaning and in adulthood," Food and Chemical Toxicology, vol. 84, pp. 64-73, 2015.

[24] J. Wang, S. Jenkins, and C. A. Lamartiniere, "Cell proliferation and apoptosis in rat mammary glands following combinational exposure to bisphenol A and genistein," BMC Cancer, vol. 14, article 379, 2014

[25] E. R. Levin, "Integration of the extranuclear and nuclear actions of estrogen," Molecular Endocrinology, vol. 19, no. 8, pp. 19511959, 2005.

[26] P. Lopez-Bergami, C. Huang, J. S. Goydos et al., "Rewired ERKJNK signaling pathways in melanoma," Cancer Cell, vol. 11, no. 5, pp. 447-460, 2007.

[27] R. Wisdom, R. S. Johnson, and C. Moore, "c-Jun regulates cell cycle progression and apoptosis by distinct mechanisms," The EMBO Journal, vol. 18, no. 1, pp. 188-197, 1999.

[28] L. M. Smith, S. C. Wise, D. T. Hendricks et al., "cJun overexpression in MCF-7 breast cancer cells produces a tumorigenic, invasive and hormone resistant phenotype," Oncogene, vol. 18, no. 44 , pp. 6063-6070, 1999. 
[29] W. Hamilton-Burke, L. Coleman, M. Cummings et al., "Phosphorylation of estrogen receptor $\beta$ at serine 105 is associated with good prognosis in breast cancer," The American Journal of Pathology, vol. 177, no. 3, pp. 1079-1086, 2010.

[30] H. Yamashita, M. Nishio, T. Toyama et al., "Low phosphorylation of estrogen receptor $\alpha(\mathrm{ER} \alpha)$ serine 118 and high phosphorylation of ER $\alpha$ serine 167 improve survival in ERpositive breast cancer," Endocrine-Related Cancer, vol. 15, no. 3, pp. 755-763, 2008.

[31] D. Zivadinovic, B. Gametchu, and C. S. Watson, "Membrane estrogen receptor-alpha levels in MCF-7 breast cancer cells predict cAMP and proliferation responses," Breast Cancer Research, vol. 7, no. 1, pp. R101-112, 2005.

[32] S. Kato, H. Endoh, Y. Masuhiro et al., "Activation of the estrogen receptor through phosphorylation by mitogen-activated protein kinase," Science, vol. 270, no. 5241, pp. 1491-1494, 1995.

[33] M. Qi and E. A. Elion, "MAP kinase pathways," Journal of Cell Science, vol. 118, no. 16, pp. 3569-3572, 2005.

[34] C.-C. Su, J. Y.-F. Chen, Z.-H. Din et al., "13-Acetoxysarcocrassolide induces apoptosis on human gastric carcinoma cells through mitochondria-related apoptotic pathways: P38/JNK activation and PI3K/AKT suppression," Marine Drugs, vol. 12, no. 10, pp. 5295-5315, 2014.

[35] C. A. Castaneda, H. Cortes-Funes, H. L. Gomez, and E. M. Ciruelos, "The phosphatidyl inositol 3-kinase/AKT signaling pathway in breast cancer," Cancer and Metastasis Reviews, vol. 29, no. 4, pp. 751-759, 2010.

[36] S. Massarweh, C. K. Osborne, C. J. Creighton et al., “Tamoxifen resistance in breast tumors is driven by growth factor receptor signaling with repression of classic estrogen receptor genomic function," Cancer Research, vol. 68, no. 3, pp. 826-833, 2008. 


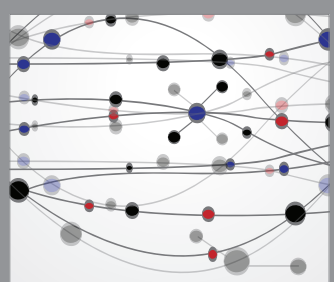

The Scientific World Journal
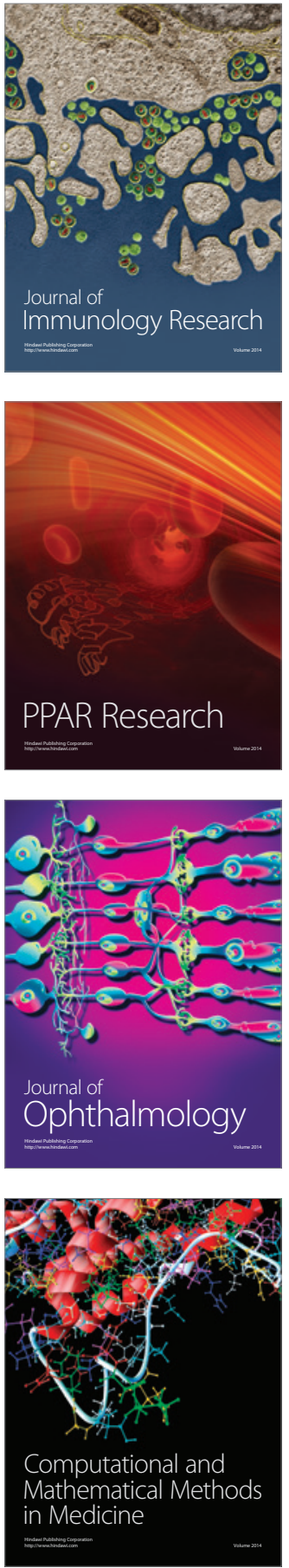

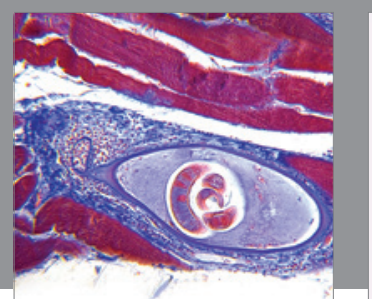

Gastroenterology Research and Practice

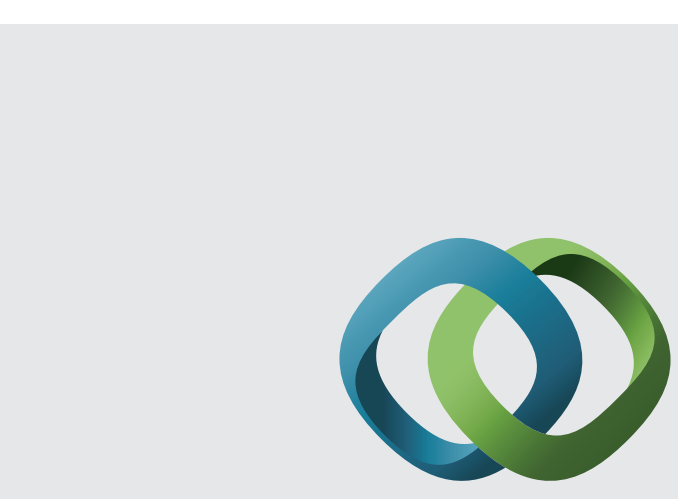

\section{Hindawi}

Submit your manuscripts at

http://www.hindawi.com
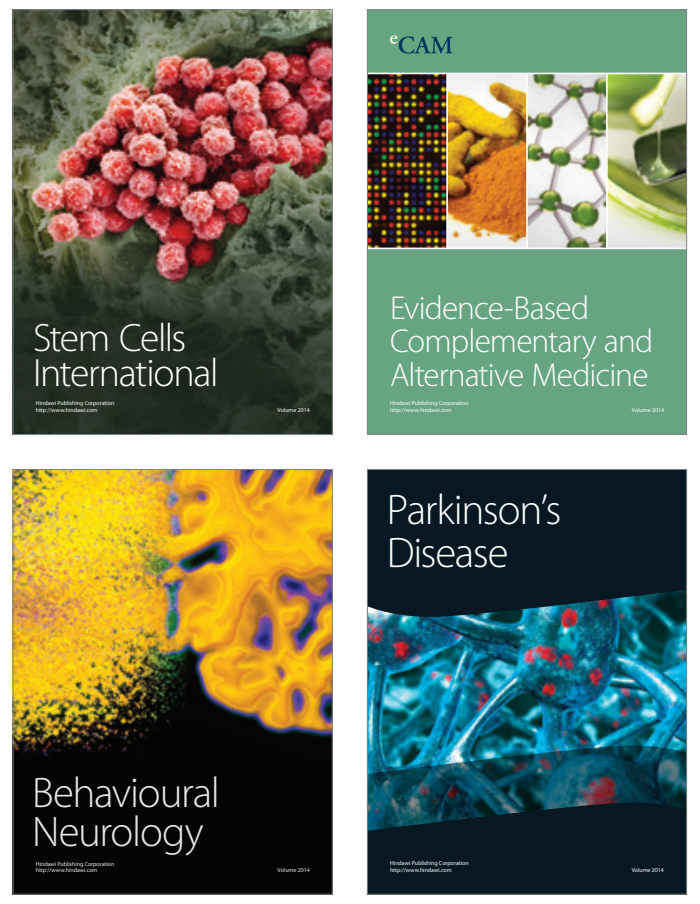
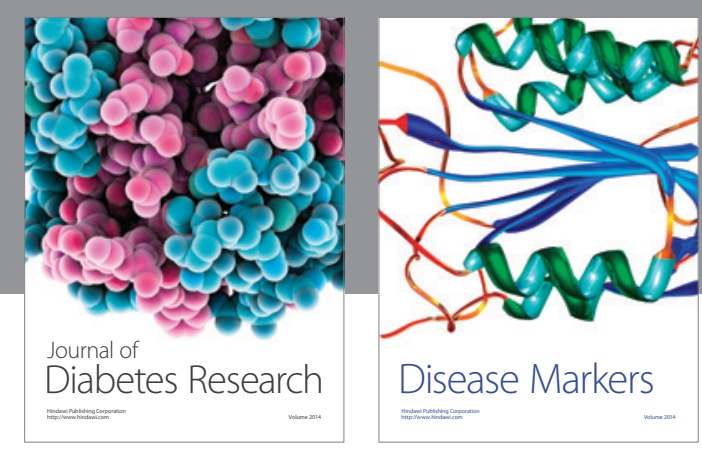

Disease Markers
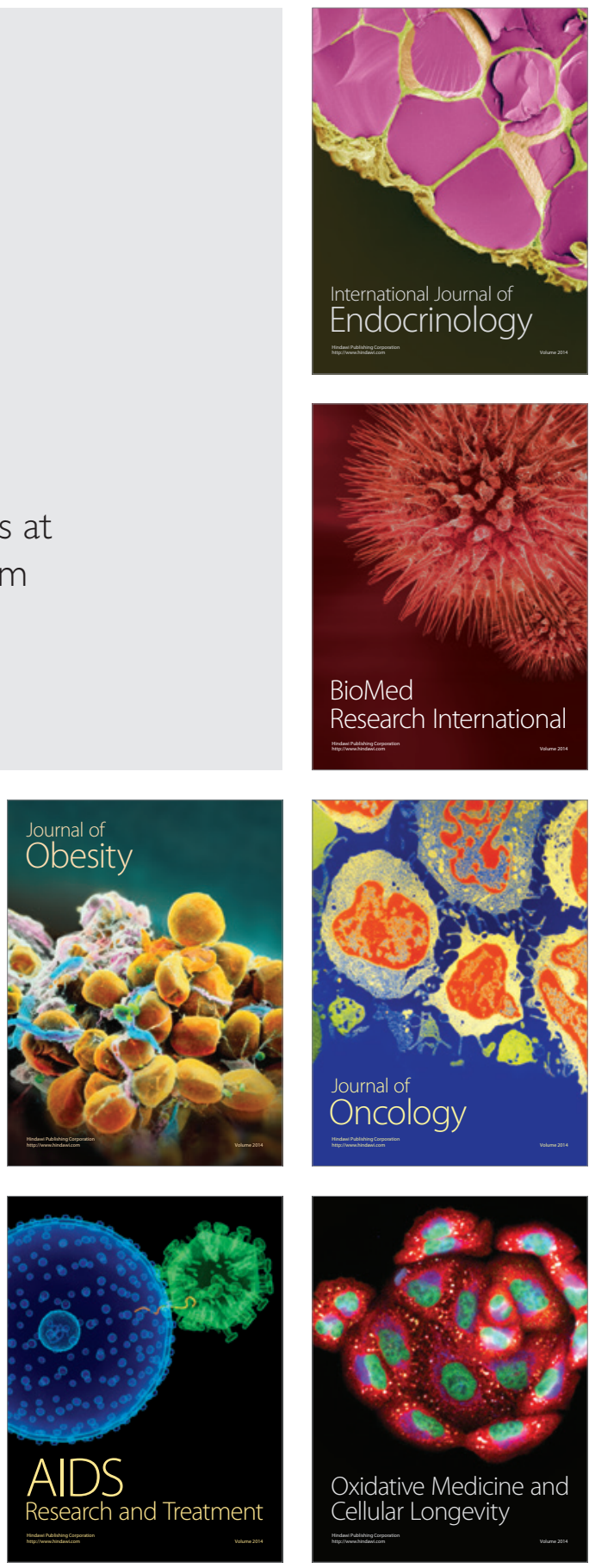